\title{
LETTER
}

\section{Flooded forests: Death by drowning, not herbivory}

\author{
White, T.C.R. \\ School of Agriculture Food and Wine, Waite Agricultural Research Institute, The University of Adelaide, P.B. 1, \\ Glen Osmond, South Australia 5064, Australia; E-mail tcrwhite@optusnet.com.au
}

\begin{abstract}
Trees on small islands formed when a new hydroelectric dam was filled are said to have been killed by leaf-cutter ants that were no longer regulated by their armadillo predators. This top-down hypothesis is questioned and an alternative bottom-up hypothesis is proposed: the trees died because their roots were flooded.
\end{abstract}

Keywords: Decline; Dieback; Drought; Population limitation/regulation; Tropical dry forest; Waterlogging.

A 'spin-off' from the general assumption that predators regulate the abundance of their prey, is the belief that if this were not so, their herbivorous prey would increase to the point where they would destroy their food plants (Hairston et al. 1960). Terborgh et al. $(2001,2006)$ supported this hypothesis. They observed the fate of semi-deciduous tropical dry forest left on islands formed when a large hydro-electric impoundment was flooded in Venezuela in 1986. Their censuses, carried out 11 and again 16 years after this flooding, revealed that while large and medium sized islands remained relatively unscathed, six small islands (0.25-0.9 ha) had been drastically altered - there had been extensive decline and death of trees left on them; and little subsequent recruitment. This devastation, the authors postulated, was because herbivores, principally leaf-cutter ants, had been left on these small islands without their predators, and so had been able to defoliate and kill the trees. They concluded that this is evidence, albeit admittedly indirect, supporting Hairston et al.'s (1960) hypothesis. Their observations have received prominent international comment and been hailed as a rare but definitive test supporting this hypothesis (Moore 2006).

I would suggest that this is not the case. While the relative role of top-down vs bottom-up control in general and in different systems is still debated, there is an extensive and growing body of evidence refuting Hairston et al.'s hypothesis and showing that herbivores' numbers are not regulated by the action of their predators, but limited by lack of adequate food in their environment (see White 1993, 2004, and references therein). Terborgh et al. (2006) nevertheless concluded that their results probably have broad generality, citing studies showing that wolves in North America exert top-down control of their prey. But Vucetich \& Peterson (2004) demonstrated that it is not their predation, but influences of the environment that limit the wolves' prey. A forest study on Barro Colorado Island showed that, contrary to Terborgh's (1992) assertion that predators regulate their prey so that they do not suffer from famine, it is not predation (even when combined with human poaching), but starvation from lack of food in times of drought that limits frugivorous mammals (Wright et al. 1999).

However, aside from this body of contrary evidence, there is an alternative and more parsimonious hypothesis to explain the observed death of trees on these newlyformed Venezuelan islands. Once the lake was filled, the roots of plants previously growing under semi-arid conditions, and on the tops of hills, were totally or partially, but permanently flooded. It is well known that this will kill the roots and lead to the decline and eventual death of those plants (Davison 1997). Even Eucalyptus camaldulensis, that grows in Australia along largely ephemeral watercourses and on infrequently flooded river flats, and has evolved to withstand many months of inundation, will eventually be killed if the flooding is too prolonged. Significantly, on these small Venezuelan islands deeprooted canopy trees rather than shallower-rooted lianas, shrubs and bamboos had died; and their seedlings, rather than those of the latter, have failed to re-establish. Judging from Moore's (2006) Fig. 1, these tiny remnants are nowhere far above the water. But even if the trees were still a metre or so above the new water line, their roots, needing to grow deeply in the previously mostly dry and well-drained soil, in a climate that frequently exposed them to drought, would have been badly affected by this new and permanent wetting of the soil. If, subsequently, the water level rose and fell over time, the alternate droughting and waterlogging of their roots - including new roots growing to adjust to a new water table - would have exacerbated and prolonged the stress of the trees, further hastening their decline.

The relationship of dieback of forests to changes in soil moisture have been well documented (Akashi \& Mueller-Dombois 1995; Auclair 1993; Davison 1997; 
White 1969, 1986). Such alternation of flooding and drying of the surface soil would also have impacted on the roots of new seedlings killing many of them. The water level of this new lake has varied by as much as $22 \mathrm{~m}$ since the initial flooding (Terborgh et al. 2006).

Some comments of Terborgh et al. (2006) vividly described the results of such flood/drought-induced dieback. "Dead twigs, branches and vine stems ... litter the ground, and in places lie in heaps." The deeper-rooted canopy trees are replaced by the more shallow-rooted plants so that "The end point ... is a nearly treeless island buried under an impenetrable tangle of liana stems."

Meanwhile, the evidence that leaf-cutter ants were responsible for the decline and death of trees because they had been freed from predation by armadillos (Dasypus novemcinctus), is not only indirect and assumed, but slight. There were no direct measurements of the impact of the ants on the trees. Saplings of species known to be favoured by the ants did not experience greater mortality. Similar numbers of ant nests were present, with and without armadillos, on the medium-sized islands where trees were much less or not at all affected (much more of the land on these larger islands could have been high enough above the new water line so that enough of the roots of their remnant vegetation could have escaped being fatally flooded).

Furthermore, the authors report that armadillos have been found to be effective at digging out young colonies of ants, but not mature ones. This is not surprising. Mature nests are huge, multi-chambered complexes, many metres deep (Moser 2006) that no armadillo could dig out. The authors also observed that the ground on these small islands was covered with red subsoil brought to the surface by worker ants. This would have been because they, too, would have been flooded, necessitating much reconstruction of their nests above the new water line.

Finally, any increase of leaf-cutter ants that might have occurred on these small islands would not have happened because of the absence of armadillos, but because of their improved survival from harvesting the more nutritious (and preferred) senescing leaves of stressed trees (Vasconcelos \& Cherrett 1996). And in the unobserved initial eleven years after flooding there may well have been other insect defoliators, still with their predators present, that attacked the trees when they were first subjected to stress but before they started to die back (Van Bael et al. 2004; White 1969, 1974).

It is now too late to do the defining experiment of removing ants from some of the small islands to see if this stopped the decline and death of the trees. But it is not too late to fence off similar-sized hill tops in the neighbouring unflooded forest, and remove armadillos from them. If the authors' hypothesis is correct, the leafcutter ants remaining in these exclosures should cause similar decline and death of the trees inside them.

\section{References}

Akashi, Y. \& Mueller-Dombois, D. 1995. A landscape perspective of the Hawaiian rain forest dieback. J. Veg. Sci. 6: 449-464.

Auclair, A.N.D. 1993. Extreme climatic fluctuations as a cause of forest dieback in the pacific rim. Water Air Soil Pollut. 66: 207-229.

Davison, E.M. 1997. Are jarrah (Eucalyptus marginata) trees killed by Phytophthora cinnamomi or waterlogging? Aust. For. 60: 116-124.

Hairston, N.G., Smith, F.E. \& Slobodkin, L.B. 1960. Community structure, population control, and competition. Am. Nat. 94: 421-424.

Moore, P.G. 2006. Green and pleasant trials. Nature 440:613614.

Moser, J.C. 2006. Complete excavation and mapping of a Texas leafcutting ant nest. Ann. Entomol. Soc. Am. 99: 891-897.

Terborgh, J. 1992. Maintenance of diversity in tropical forests. Biotropica 24: 283-292.

Terborgh, J., Feeley, K., Silman, M., Nuñez, P.\& Balukjian, B. 2006. Vegetation dynamics of predator-free land-bridge islands. J. Ecol. 94: 253-263.

Terborgh, J., Lopez, L., Nuñez, P., Rao, M., Shahabuddin, G., Orihuela, G., Riveros, M., Ascanio, R., Adler, G.H., Lambert, T.D. \& Balbas, L. 2001. Ecological meltdown in predator-free forest fragments. Science 294: 1923-1926.

Van Bael, S.A., Aiello, A., Valderrama, A., Merianero, E., Samaniego, M. \& Wright, S.J. 2004. General herbivore outbreak following an El Niño-related drought in lowland Panamanian forest. J. Trop. Ecol. 20: 625-633.

Vasconcelos, H.L. \& Cherrett, J.M. 1996. The effect of wilting on the selection of leaves by the leaf-cutting ant Atta laevigata. Entomol. Exp. Appl. 78: 215-220.

Vusetich, J.A. \& Peterson, R.O. 2004. The influence of topdown, bottom-up and abiotic factors on the moose (Alces alces) population of Isle Royale. Proc. R. Soc. Lond. B. 271: 183-189.

White, T.C.R. 1969. An index to measure weather-induced stress of trees associated with outbreaks of psyllids in Australia. Ecology 50: 905-909.

White, T.C.R. 1974. A hypothesis to explain outbreaks of looper caterpillars, with special reference to populations of Selidosema suavis in plantations of Pinus radiata in New Zealand. Oecologia 16: 279-301.

White, T.C.R. 1986. Weather, Eucalyptus dieback in New England, and a general hypothesis of the cause of dieback. Pac. Sci. 40: 58-78.

White, T.C.R. 1993. The inadequate environment: nitrogen and the abundance of animals. Springer-Verlag, Berlin, DE.

White, T.C.R. 2004. Limitation of populations by weatherdriven changes in food: a challenge to density-dependent regulation. Oikos 105: 664-666.

Wright, S.J., Carrasco, C., Calderon, O. \& Paton, S. 1999. The El Niño Southern Oscillation, variable fruit production, and famine in a tropical forest. Ecology 80: 1632-1647.

Co-ordinating Editor S. Díaz. 
Copyright of Journal of Vegetation Science is the property of Opulus Press and its content may not be copied or emailed to multiple sites or posted to a listserv without the copyright holder's express written permission. However, users may print, download, or email articles for individual use. 